\title{
Metabolism of mesopelagic and bathypelagic copepods in the western North Pacific Ocean
}

\author{
Tsutomu Ikeda*, Fumikazu Sano, Atsushi Yamaguchi, Takashi Matsuishi \\ Graduate School of Fisheries Sciences, Hokkaido University, Minato-cho, Hakodate, 041-8611, Japan
}

\begin{abstract}
Respiration (= oxygen consumption) rates and electron transport system (ETS) enzyme activities in conjunction with body carbon and nitrogen composition (for respiration) or protein (for ETS) were determined for over 50 copepod species from the mesopelagic ( $\mathrm{M}_{i} 500$ to $\left.1000 \mathrm{~m}\right)$, upperbathypelagic (UB; 1000 to $2000 \mathrm{~m}$ ) and lower-bathypelagic (LB; 2000 to $3000 \mathrm{~m}$ ) zones of the western subarctic Pacific. Calculated specific respiration rates (SR, a fraction of body carbon respired) at in situ temperatures $\left(3,2\right.$ and $1.5^{\circ} \mathrm{C}$ for the $\mathrm{M}, \mathrm{UB}$ and LB zones, respectively) were greater for the $\mathrm{M}$ zone copepods (mean: $1.1 \%$ body $\mathrm{C} \mathrm{d}^{-1}$ ) than that for the UB and LB zone copepods (both $0.6 \%$ body $\mathrm{C} \mathrm{d}^{-1}$ ). Respiration rates adjusted to those at $1{ }^{\circ} \mathrm{C}$ by using a $Q_{10}$ value $(2.0)$, and to those of specimens with $1 \mathrm{mg}$ body nitrogen by using a body mass exponent (0.8) (e.g. adjusted metabolic rates, AMR, in $\mu \mathrm{l} \mathrm{O}_{2}$ (mg body $\mathrm{N}^{-0.8} \mathrm{~h}^{-1}$ ) were also greater for the M zone copepods than for the UB and LB zone copepods. ETS activities, measured as $\mu \mathrm{O} \mathrm{O}_{2}$ (mg protein) ${ }^{-0.8} \mathrm{~h}^{-1}$, showed the same depth-related decline from the $\mathrm{M}$ zone to the LB zone. Stepwise regression analysis revealed that stage/sex, feeding type and/or reaction speeds (as judged by the presence/absence of myelin sheath enveloping axons) of copepods were possible additional variables affecting their respiration rates and ETS activities. The reduction in respiration rates and ETS activities from the M zone to the UB or LB zone is more pronounced when respiration rate data on Arctic/Antarctic epipelagic copepods is added; the same is true for ETS activities when respiration rate data is added from copepods dominant in the subarctic Pacific. The present results are compared with those of micronektonic crustaceans and fishes reported for specimens collected from 500 to $2000 \mathrm{~m}$ in other regions and discussed in the light of the 'visual interactions' hypothesis.
\end{abstract}

KEY WORDS: Mesopelagic $\cdot$ Bathypelagic $\cdot$ Copepods $\cdot$ Respiration $\cdot$ ETS activity $\cdot$ Western North Pacific

\section{INTRODUCTION}

As multicellular organisms, copepod crustaceans may be the most numerous on earth, outnumbering even insects, though the latter have higher species diversity (Mauchline 1998). Copepods occur in a broad range of aquatic, primarily marine, environments and their adult sizes are typically 0.3 to $20 \mathrm{~mm}$ (Mauchline 1998). Among various animal taxa occurring as plankton in the pelagic realm of the ocean, copepods are the most numerous (55 to $95 \%$; Longhurst 1985). Because of their ubiquitous distribution throughout the ocean interior and their high abundance, it is necessary to integrate information on factors affecting the metabolic activities of marine pelagic copepods in order to better understand their roles in energy flow and biogeochemical cycles in the world's ocean.

Studies have shown that body mass and habitat temperature are 2 major variables which affect the metabolic rates of marine pelagic copepods living in the epipelagic realm of the world's ocean (Ikeda et al. 2001). However, there has been little investigation regarding whether or not the metabolic rate-body mass-temperature relationship established for epipelagic copepods by Ikeda et al. (2001) is applicable to those living in mesopelagic and bathypelagic zones 
that are characterized by little or no daylight, high hydrostatic pressure and often low oxygen concentrations. Thuesen et al. (1998) made an extensive study off the California coast and noted the lack of depthrelated changes in the metabolic rates of pelagic copepods. However, no studies have been made to confirm their results in other regions of the world's ocean. In relation to the entire earth ecosystem, the epipelagic zone (E: 0 to $200 \mathrm{~m}$ ) occupies only a modest fraction $(5.4 \%)$ of the volume $\left(1350 \times 10^{6} \mathrm{~km}^{3}\right.$; Menard \& Smith 1966) of the world's oceans, which have an average depth of $3700 \mathrm{~m}$. There is an urgent need to gain more information about the metabolic features of deep-sea copepods in order to understand the global role of zooplankton over the full depth of the sea (HernandezLeon \& Ikeda 2005a). For micronektonic fishes and crustaceans, it has been confirmed that the depth of occurrence is the third variable affecting their metabolic rates (cf. Childress 1995).

In this study, we determined respiration (= oxygen consumption) rates of live copepods retrieved by shipboard sampling from mesopelagic (M: 500 to $1000 \mathrm{~m}$ ), upper-bathypelagic (UB: 1000 to $2000 \mathrm{~m}$ ) and lowerbathypelagic (LB: 2000 to $3000 \mathrm{~m}$ ) zones in the western subarctic Pacific. As another measure of respiration potential, enzyme activities of the electron transfer system (ETS) were also measured using frozen specimens. From these results, a new hypothesis for depth-related respiration rates of pelagic copepods is proposed.

\section{MATERIALS AND METHODS}

Copepods. Specimens were collected at stations in the western subarctic Pacific, including Site $\mathrm{H}$ $\left(41^{\circ} 30^{\prime} \mathrm{N}, 145^{\circ} 50^{\prime} \mathrm{E}\right)$, Stn Knot $\left(44^{\circ} 00^{\prime} \mathrm{N}, 155^{\circ} 00^{\prime} \mathrm{E}\right)$ during TS 'Oshoro-Maru' cruises 124A (June) in 2002; 133D (March), 136A (June) and 142A (December) in 2003; 143B (February) and 144A (March) in 2004; and 155 (March) in 2005. A vertical closing net (diameter $80 \mathrm{~cm}$, modified from Kawamura 1968) equipped with a large cod-end ( 1 to 21 capacity) was used to retrieve live zooplankton from the M, UB, and LB zones. The closing net was towed from the bottom to the top of designated depth stratum at a speed of $1 \mathrm{~m} \mathrm{~s}^{-1}$, closed and retrieved to the surface at $2 \mathrm{~m} \mathrm{~s}^{-1}$. The depth the net reached was read from the record of an RMD depth meter (Rigosha) attached to the suspension cable of the net. After closing the mouth of the net at the designated depth, the time required to retrieve the net to the surface was at most 17 min (when closed at $2000 \mathrm{~m}$ depth). During this study, a closing cod-end was developed (T. Ikeda unpubl.) to maintain near the in situ temperature of the zooplankton samples during the course of net retrieval and used when the water temperature at the surface layer exceeded $>10^{\circ} \mathrm{C}$. In addition to the closing net, a ring net was also used to collect zooplankton from the $\mathrm{E}$ zone, all of which were used for ETS assay only.

Upon retrieval of the net, undamaged specimens were sorted immediately. Sorted specimens were placed in $1 \mathrm{l}$ glass containers filled with seawater from the mid-depth range of their collection (e.g. 750, 1500 and $2500 \mathrm{~m}$ for the specimens collected from M, UB and LB zones, respectively). The seawater was collected with 201 Niskin bottles just prior to zooplankton collection for each experiment. Temperature and salinity profiles were determined by using a CTD system.

Respiration. A sealed-chamber method (cf. Ikeda et al. 2000) using small glass bottles (40 to $70 \mathrm{ml}$ capacity) was used to determine copepods respiration rates. It is noted that the 1000 to $2000 \mathrm{~m}$ depth in the western North Pacific is characterized by moderately low oxygen levels (1.0 to $2.0 \mathrm{ml} \mathrm{O}_{2} \mathrm{l}^{-1}$, or 10 to $30 \%$ saturation; Favorite et al. 1976), a parameter affecting respiration rates of zooplankton (cf. Ikeda et al. 2000). In order to obtain respiration rates under near natural oxygen concentrations, seawater was first filtered gently through $10 \mu \mathrm{m}$ mesh netting to remove large particles (the oxygen concentration of seawater thus prepared for copepods from 1000 to $2000 \mathrm{~m}$ was 1.6 to $2.0 \mathrm{ml} \mathrm{O}$ $\mathrm{l}^{-1}$ ). Experiments started within 1 to $3 \mathrm{~h}$ after collection of the specimens. Experimental bottles containing specimens (usually 1 individual) and control bottles without specimens were prepared simultaneously and incubated in the dark for $24 \mathrm{~h}$ at in situ temperatures, e.g. $3^{\circ} \mathrm{C}$ for the $\mathrm{M}$ zone, $2^{\circ} \mathrm{C}$ for the UB zone and $1.5^{\circ} \mathrm{C}$ for the LB zone under 1 atmosphere (atm) pressure. At the end of each experiment, dissolved oxygen concentration was determined by the Winkler titration method on subsamples siphoned from the bottles into 2 small oxygen vials ( 7 or $14 \mathrm{ml}$ capacity). Based on replicate measurements on a homogenous water sample, the precision expressed as the coefficient of variation (CV) was estimated as $0.2 \%$.

For copepods from the UB zone, respiration rates were determined either under normal pressure (1 atm) or applying a pressure of $100 \mathrm{~atm}$ (equivalent to the hydrostatic pressure at $1000 \mathrm{~m}$ depth) in an attempt to detect the effect of hydrostatic pressure. For the experiment at $100 \mathrm{~atm}$, a newly designed recompression chamber (capacity: $100 \mathrm{~mm}$ diameter $\times 100 \mathrm{~mm}$ depth, Tsurumi Seiki) equipped with a hand-operated hydraulic pump (Model PH-10, Yamasui) was used. At the start and end of the experiments, pressure was rapidly applied to or released from the chamber, i.e. almost immediately. General experimental procedures were the same as those mentioned above. 
All specimens used for experiments were rinsed briefly with small amounts of chilled distilled water, blotted on filter paper and frozen at $-60^{\circ} \mathrm{C}$ on board the ship for later determination of wet weight (WW), dry weight (DW), and carbon (C) and nitrogen (N) composition at a land laboratory. Frozen specimens were weighed at WW and then freeze-dried to obtain DW. A microbalance (Mettler Toledo MT5) was used for weighing to a precision of $1 \mu \mathrm{g}$. Prior to body composition analyses, copepods were identified to species under a dissecting microscope. At the same time, their developmental stages and sexes (whenever possible) were recorded. Specimens of the same species from the same depth strata were pooled in each cruise and used for $\mathrm{C}$ and $\mathrm{N}$ composition analysis with a CHN elemental analyzer (Elementar vario EL) using acetanilide as a standard. Precision (CV) of these measurements was $3 \%$ for $\mathrm{C}$ and $7 \%$ for N. Only $\mathrm{C}$ and $\mathrm{N}$ data were used to standardize the respiration data of each copepod in the present study, and details about the biometry and body composition will be published elsewhere.

ETS activity. Freshly collected specimens were identified to species under the dissecting microscope, preserved immediately in liquid nitrogen on board the ship and brought back to the land laboratory for ETS assay. Within 1 mo after the collection, the frozen specimens were weighed quickly (WW) whenever possible and homogenized together with a small piece of glass fiber filter in a glass-teflon tissue homogenizer. The method described by Owens \& King (1975) was used for this assay, but the final reaction volume was reduced from 6 to $1.5 \mathrm{ml}$. One $\mathrm{ml}$ homogenized samples in ETS-B solution were centrifuged, and the cellfree extract thus obtained was used for ETS assay. Preliminary tests indicated that the ETS activities of single specimens were too low to measure at in situ temperatures $\left(1.5\right.$ to $\left.3^{\circ} \mathrm{C}\right)$. To overcome this problem, all assays were made at a fixed temperature of $10^{\circ} \mathrm{C}$. ETS activities were determined on two $0.25 \mathrm{ml}$ aliquots of cell-free extract of each sample. The effect of hydrostatic pressure on ETS activities of crustacean plankton has been demonstrated to be insignificant at least to 265 atm (King \& Packard 1975a). Since the measurement of WW was not feasible for all specimens, protein concentrations were determined on each homogenate as an alternative to ascertain the body mass of the specimens analyzed. Protein was determined in duplicate by the method of Lowry et al. (1951) using bovine serum albumin as a standard.

Data analysis. Individual data representing 1 or a number of specimens from various seasons of the year were pooled in the following analyses.

Specific respiration $(\boldsymbol{S R})$ : From respiration rates ( $R: \mu \mathrm{l} \mathrm{O}$ ind $^{-1} \mathrm{~h}^{-1}$ ), SR were calculated as the amount of $\mathrm{CO}_{2}-\mathrm{C}$ lost through respiration daily (\% body $\mathrm{C} \mathrm{d}^{-1}$ ) at in situ temperature and expressed as a fraction of body $C_{\text {; }} \mathrm{SR}=R \times 0.97 \times 24 \times(12 / 22.4) \times 10^{-3} \times 100(\mathrm{mg}$ body $\mathrm{C}^{-1}$, where 0.97 is a respiratory quotient (RQ) for protein metabolism (Gnaiger 1983), 24 is the number of hours $\mathrm{d}^{-1}, 12 / 22.4$ is $\mathrm{C}$ mass in $1 \mathrm{~mol}$ of $\mathrm{CO}_{2}$ (22.4 l), and $10^{-3}$ is to convert $\mu \mathrm{g}$ to $\mathrm{mg}$.

Adjusted metabolic rate (AMR): A body mass exponent (0.8) and a $Q_{10}$ value (2) derived from a comprehensive analysis of respiration-body mass datasets of epipelagic copepods in the world's ocean (Ikeda et al. 2001) were used to compare respiration rates of specimens with different body mass determined at different temperatures. The same exponent and $Q_{10}$ values were also used to standardize ETS activities on the grounds that ETS:respiration ratios are independent of either the habitat temperature or body mass of various marine zooplankton (King \& Packard 1975b). In this way, both respiration rates determined at in situ temperatures and ETS activities at $10^{\circ} \mathrm{C}$ were finally expressed as the rates or activities of specimens with $1 \mathrm{mg}$ body $\mathrm{N}$ (AMR: $\mu \mathrm{O}_{2}$ (mg body $\left.\mathrm{N}\right)^{-0.8} \mathrm{~h}^{-1}$ ) at $1^{\circ} \mathrm{C}$. Body mass of specimens used for ETS assay was measured as protein, and converted to nitrogen by using the equation: protein $=5$ $\times$ nitrogen (T. Ikeda unpubl. data). Among various body mass units (wet mass, dry mass, carbon mass, etc.), nitrogen has been shown to be superior for in interspecific comparison of metabolic rates of marine pelagic copepods and zooplankton in general (Ikeda 1985, Ikeda et al. 2001). The temperature $1^{\circ} \mathrm{C}$ was chosen as the mid-range of habitat temperatures of mesopelagic/ bathypelagic copepods in the western subarctic Pacific of our study $\left(1.5\right.$ to $\left.3^{\circ} \mathrm{C}\right)$ and that of epipelagic copepods in Arctic/Antarctic waters $\left(-2.3\right.$ to $-1.7^{\circ} \mathrm{C}$, Ikeda et al. 2001). The latter data were combined with the present data to evaluate the depth-related decline in the respiration rates (see below).

Epipelagic respiration data: To facilitate analysis of the effect of habitat depth on the respiration rates of copepods on the basis of similar habitat temperatures, part of the epipelagic data for copepods in the world's ocean (Ikeda et al. 2001) was combined with the mesopelagic/bathypelagic data of the present study. The epipelagic data used in the present analysis are those of Calanus propinquus, Calanoides acutus, Rhincalanus gigas and Metridia gerlachei from Antarctic waters, and Calanus finmarchicus, C. glacialis, C. hyperboreus and $M$. longa from Arctic waters; body masses for all of the species above fell well within the range of those of the copepods examined in the present study (from the 28 data sets for $C$. acutus copepodid stages 4 to 5 (C4-C5), 8 data sets for very small specimens, i.e. $<0.1 \mathrm{mg} \mathrm{DW}$, were omitted). Copepods in the Ikeda et al. (2001) study were exposed to the same experimental conditions as in the present study, except that in their study a batch of 5 to 20 ind. were incubated 
in ca. $300 \mathrm{ml}$ bottles (in contrast to mostly single individuals incubated in 40 to $70 \mathrm{ml}$ bottles in our study). In order to maintain consistency of the data, the original data from each experimental bottle rather than the means in Ikeda et al. (2001) were used for comparison with the present results. These epipelagic respiration data were converted to SR (\% body $\left.\mathrm{C} \mathrm{d}^{-1}\right)$ at the in situ temperature and AMR $\left(\mu l \mathrm{O}_{2}(\operatorname{mg} \text { body } N)^{-0.8} \mathrm{~h}^{-1}\right)$ at $1^{\circ} \mathrm{C}$ using the same $Q_{10}$ value (2) and body mass exponent value $(0.8)$ mentioned above.

\section{RESULTS}

\section{Copepods}

Calanoid copepod species belonging to the 6 superfamilies (Arietelloidea, Centropagoidea, Clausocalanoidea, Euclanidea, Megacalanoidea, and Spinocalanoidea) and 11 families (Aetideidae, Scolecitrichidae, Euchaetidae, Metridinidae, Lucicutiidae, Augaptilidae, Phannidae, Spinocalanidae, Hetrorhabdidae, Candaciidae and Megacalanidae) were used for both respiration experiments and ETS assays in the present study (Table 1). Among the superfamilies, Arietelloidea and Centropagoidea have been considered ancient and the rest considered as more recently evolved, as judged by the absence or presence, respectively, of myelin sheathes enveloping axons (Lenz et al. 2000). Interzonal species belonging to the families Eucalanidae (Eucalanus bungii) and Calanidae (Neocalanus cristatus and $N$. plumchrus) from the epipelagic zone were used for ETS assay, but those from the mesopleagic and bathypelagic zones were not used in either ETS or respiration experiments since their respiration rates are supposed to be under the effect of diapause, e.g. no feeding, neutral buoyancy and lowered metabolic rates (cf. Ikeda et al. 2004). Within the same species, the data for each developmental stage, for males and females and from different cruises were treated separately. As a result, the number of respiration datasets was 54 for $36 \mathrm{M}$ zone copepods, 57 for 32 UB zone copepods and 47 for 27 LB zone copepods. Many species occurred from 2 neighbouring bathymetric zones, and some (Metridia asymmetrica, Pseudochirella spinifera, Paraeuchaeta birostrata and P. rubra) from all 3 bathymetric zones. Similarly, the number of ETS datasets was 17 for $12 \mathrm{E}$ zone copepods, 28 for $26 \mathrm{M}$ zone copepods, 21 for 13 UB zone copepods and 31 for 25 LB zone copepods, with several species in common among the 3 bathymetric zones (Appendices 1 \& 2; www.int-res.com/ articles/suppl/m322p199_app.pdf). The total number of copepod species studied was 59 for respiration experiments and 54 for ETS assay.
Table 1. Copepod genera used for respiration experiments and electron transport system (ETS) assay in the present study or $\left({ }^{*}\right)$ Arctic/Antarctic copepods cited from Ikeda et al. (2001)

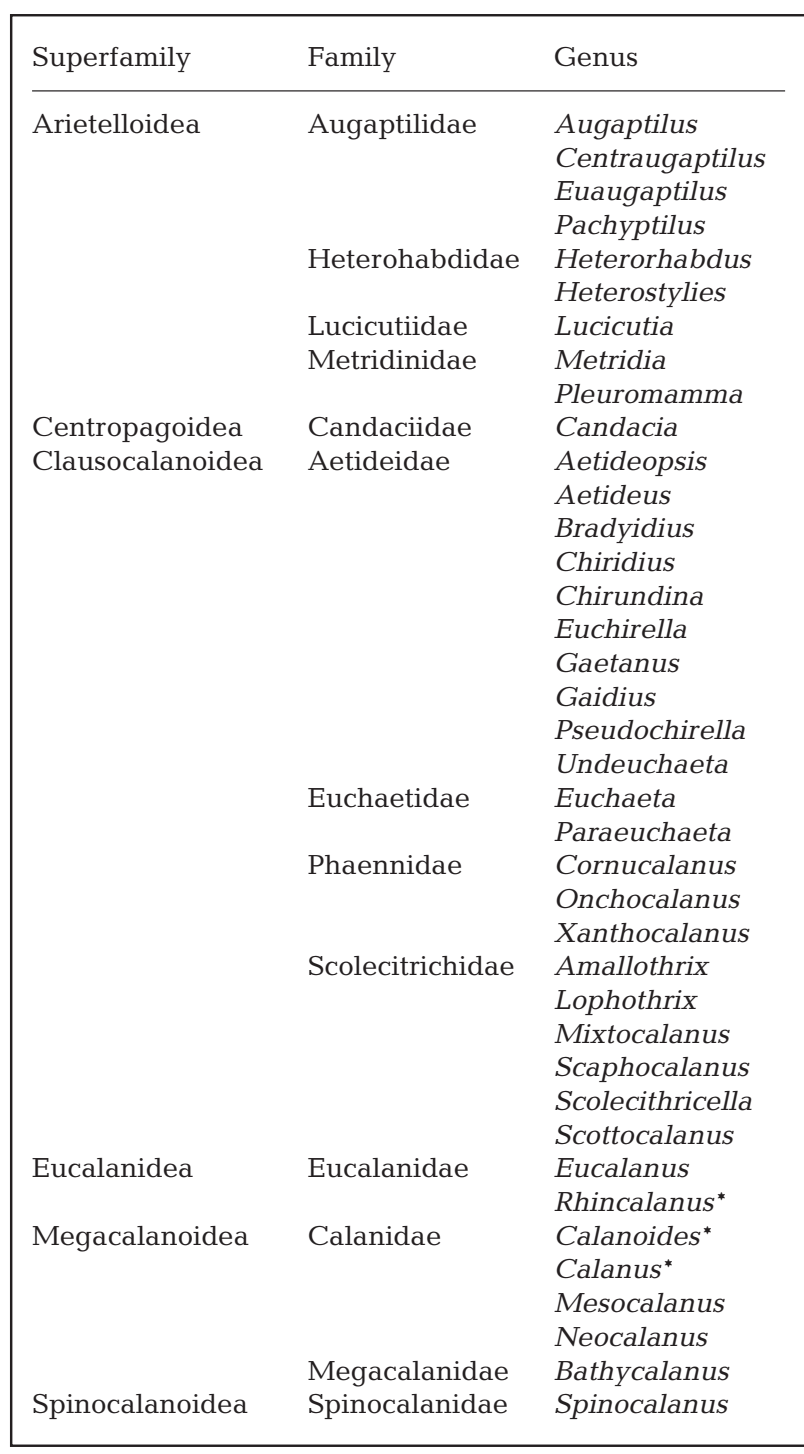

\section{Respiration}

Across the 3 depth strata, body $\mathrm{C}$ of copepods included in experiments ranged from 0.13 (Gaidius variabilis $\mathrm{C} 5 \mathrm{~F}$ from the $\mathrm{M}$ zone) to $21.8 \mathrm{mg}$ (Bathycalanus bradyi C6F from the UB zone), and body $\mathrm{N}$ from 0.025 (Metridia asymmetrica C6F from the UB zone) to $2.38 \mathrm{mg}$ (B. bradyi C6F from the UB zone). Respiration rates varied from 0.05 ( $M$. asymmetrica C6F from the UB zone) to $4.17 \mu \mathrm{O}_{2}$ ind. $^{-1} \mathrm{~h}^{-1}$ (B. bradyi $\mathrm{C} 6 \mathrm{~F}$ from the UB zone) (Appendix 1). Plots of respiration rates against body masses for the present data and for those of Arctic/Antarctic E zones on a log-log graph showed a pattern of linear increase in the former with 
an increase in the latter. At the same time, the intercepts of regression lines fitted with a designated common slope (0.8) varied with depth zone, with copepods from with the E zone being the highest, followed by those from the $\mathrm{M}$ zone and UB/LB zones (Fig. 1A).

For 13 individual copepods from the UB zone, respiration rates were measured successfully in the recompression chamber (100 atm) (Appendix 1). The choice of $100 \mathrm{~atm}$ was purely due to the size of the recompression chamber we can accommodate in the incubators of the ship's laboratory. The resultant respiration rate at $100 \mathrm{~atm}$, expressed as AMR $\left(\mu \mathrm{l} \mathrm{O} \mathrm{mg} \mathrm{N}^{-0.8} \mathrm{~h}^{-1}\right)$ at $1^{\circ} \mathrm{C}$, was $1.53( \pm 0.62 \mathrm{SD} ; \mathrm{n}=21)$, which did not differ significantly from $1.82( \pm 0.75 \mathrm{SD} ; \mathrm{n}=98)$, which was the rate determined at $1 \mathrm{~atm}$ of copepods from the same depth stratum $(t=1.68, \mathrm{df}=117, \mathrm{p}>0.10)$. Based on this result, the respiration data at $100 \mathrm{~atm}$ and $1 \mathrm{~atm}$ for copepods from the UB zone were pooled in the following analyses (Appendix 1).

SR (\% body $\mathrm{C} \mathrm{d}^{-1}$ ) at in situ temperature and AMR $\left(\mu \mathrm{l} \mathrm{O}_{2}(\mathrm{mg} \text { body } \mathrm{N})^{-0.8} \mathrm{~h}^{-1}\right)$ at $1^{\circ} \mathrm{C}$ ranged from 0.31 to 2.45 (mean = 1.05) and from 0.77 to $4.21(2.49)$, respectively, for the M zone copepods, from 0.17 to 1.85 (0.60) and from 0.50 to 2.98 (1.78), respectively, for the UB zone copepods, and from 0.14 to $1.38(0.56)$ and from 0.42 to 3.50 (1.80), respectively, for the LB zone copepods (Appendix 1).

One-way ANOVA and subsequent between-mean tests (Bonferroni-test) revealed that both $\mathrm{SR}$ at in situ temperature and $\mathrm{AMR}$ at $1^{\circ} \mathrm{C}$ from the $\mathrm{E}, \mathrm{M}, \mathrm{UB}$ and $\mathrm{LB}$ zones were significantly inhomogeneous $(F=64.89$, df
$=3,244, \mathrm{p}<0.001$ for $\mathrm{SR}$, and $F=7,207$, df $=3,244$, $\mathrm{p}<0.001$ for AMR) and differences among means were $\mathrm{E}>\mathrm{M}>\mathrm{UB}=\mathrm{LB}$ in both variables.

All of the AMR data from the M, UB and LB zones in Appendix 1 were pooled and regrouped into 4 developmental stage/sex groups (C5F, C5M, C6F or C6M), 3 feeding types (carnivore, detritivore or suspension feeder; cf. Arashkevich 1969, Yamaguchi et al. 2002), or 2 groups based on presence or absence of myelinated sheath enveloping axons (see Lenz et al. 2000). In the 4 developmental stage/sex groups, $4 \mathrm{C} 4$ data and 2 C5 data without sex identification were omitted. Then the differences in AMRs at $1^{\circ} \mathrm{C}$ among groups or types were analyzed by 1-way ANOVA and the Bonferroni-test for paired means (Table 2). As a result, no significant effect of the stage/sex on AMRs was detected. On the other hand, feeding types affected AMRs and carnivores exhibited significantly lower rates than the other 2 feeding types. Slow-reacting copepods (myelinated sheath absent) exhibited significantly lower AMRs than fast-reacting copepods (myelinated sheath present). Within the groups or feeding types the differences in the depth of occurrence were not significant (Table 2).

\section{ETS}

Across the 4 bathymetric strata, body protein of copepods assayed varied from $0.06 \mathrm{mg}$ (Euaugaptilus pseudaffinis C4 from the LB zone and Pleuromamma
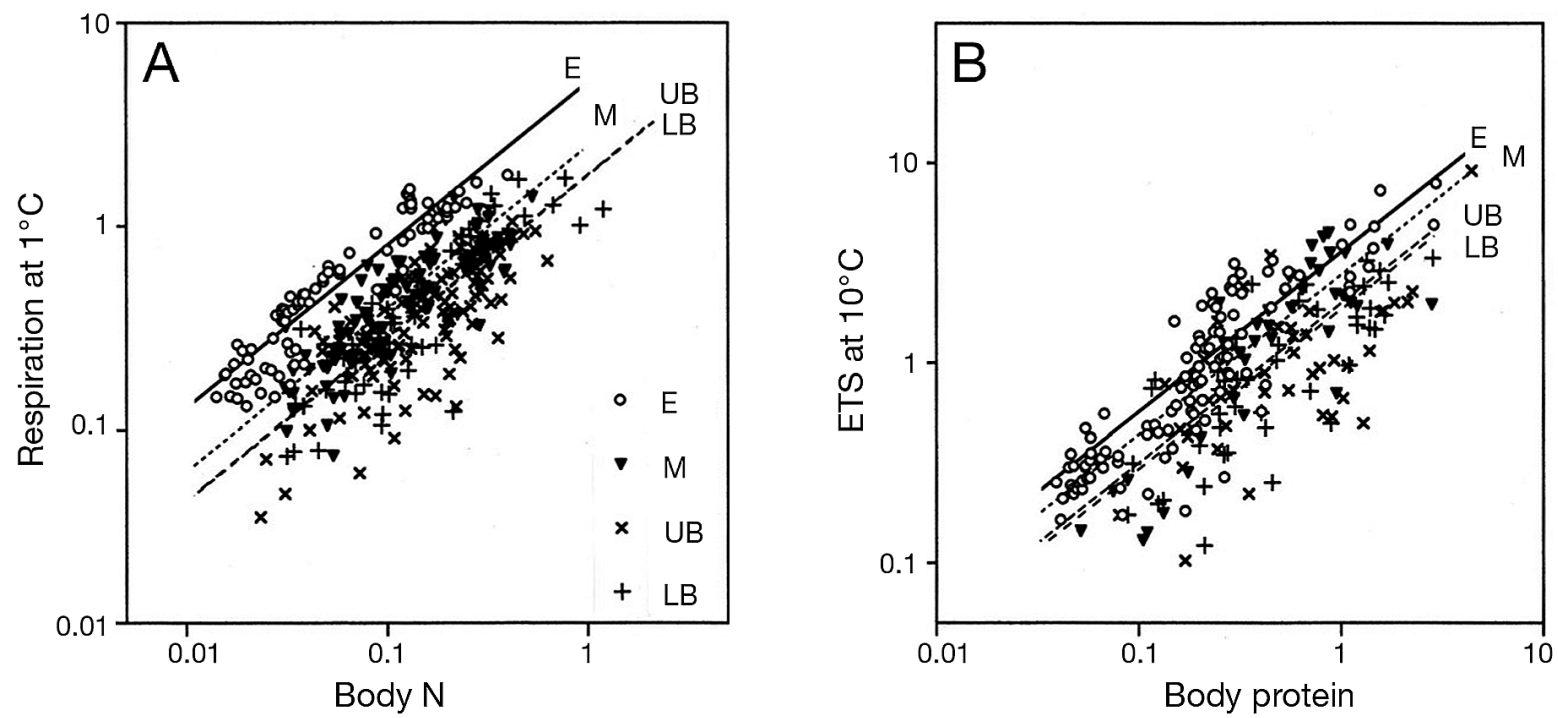

Fig. 1. Scatter diagrams showing the relationship (A) between respiration rates at $1^{\circ} \mathrm{C}\left(\mu \mathrm{l} \mathrm{O}_{2}\right.$ ind. $\left.{ }^{-1} \mathrm{~h}^{-1}\right)$ and body nitrogen $\left(\mathrm{mg}\right.$ ind. $\left.{ }^{-1}\right)$, and (B) between electron transport system (ETS) activities at $10^{\circ} \mathrm{C}\left(\mu \mathrm{O}_{2}\right.$ ind..$\left.^{-1} \mathrm{~h}^{-1}\right)$ and body protein (mg ind. $\left.{ }^{-1}\right)$ of copepods from the epipelagic (E), mesopelagic (M), upper-bathypelagic (UB) and lower-bathypelagic (LB) zones. Data are from the subarctic Pacific, except for E zone respiration data, which are from Arctic/Antarctic waters (Ikeda et al. 2001). Fitted regression lines for respective depth zone data are $y=0.8 x+\gamma$, where $\gamma$ is the mean adusted metabolic rate (AMR) at $1^{\circ} \mathrm{C}$ for respiration-N relations in Appendix 1, and mean ETS $\left(\mu \mathrm{O}_{2}\right.$ protein $\left.^{-0.8} \mathrm{~h}^{-1}\right)$ for ETS-protein relations in Appendix 2 

copepods split into 4 stage/sex groups (C5F, C5M, C6F, C6M), 3 feeding types (C: carnivore, D: detritivore, S: suspension feeder) or 2 groups based on the absence (A) or presence (P) of myelinated sheath. Values are $\mathrm{n}$ (number of datasets), mean and SD. Differences between groups or types and between associated depths of occurrence were examined using 1-way ANOVA. Significant differences between paired means were tested using the Bonferroni-test at the $p=0.05$ level. ns: not significant $(p>0.05)$

\begin{tabular}{|c|c|c|c|c|c|}
\hline \multirow[t]{2}{*}{ Source of variation } & \multicolumn{3}{|c|}{$\begin{array}{c}\operatorname{AMR}\left(\mu l \mathrm{O}_{2} \mathrm{mgN}^{-0.8} \mathrm{~h}^{-1}\right) \\
\text { at } 1^{\circ} \mathrm{C}\end{array}$} & \multicolumn{2}{|c|}{ Depth (m) } \\
\hline & $\mathrm{n}$ & Mean & $\mathrm{SD}$ & Mean & $\mathrm{SD}$ \\
\hline \multicolumn{6}{|l|}{ Stage/sex } \\
\hline $\mathrm{C} 5 \mathrm{~F}$ & 21 & 1.98 & 0.67 & 1571 & 681 \\
\hline C5M & 22 & 2.13 & 0.77 & 1386 & 702 \\
\hline $\mathrm{C} 6 \mathrm{~F}$ & 93 & 2.08 & 0.81 & 1570 & 703 \\
\hline \multirow[t]{2}{*}{$\mathrm{C} 6 \mathrm{M}$} & 16 & 1.72 & 0.50 & 1625 & 683 \\
\hline & \multicolumn{3}{|c|}{$\begin{array}{c}1.193(3,148) \\
0.315^{\text {ns }}\end{array}$} & \multicolumn{2}{|c|}{$\begin{array}{c}0.497(3,148) \\
0.685^{\text {ns }}\end{array}$} \\
\hline \multicolumn{6}{|l|}{ Feeding type } \\
\hline $\mathrm{C}$ & 45 & 1.76 & 0.61 & 1372 & 692 \\
\hline D & 26 & 2.26 & 0.65 & 1654 & 588 \\
\hline S & 87 & 2.10 & 0.84 & 1595 & 728 \\
\hline $\begin{array}{r}F(\mathrm{df}): \\
\mathrm{p}: \\
\text { Post hoc: }\end{array}$ & \multicolumn{3}{|c|}{$\begin{array}{c}4.413(2,155) \\
0.014 \\
D=S>C\end{array}$} & \multicolumn{2}{|c|}{$\begin{array}{c}1.921(2,155) \\
0.150^{\mathrm{ns}}\end{array}$} \\
\hline \multicolumn{6}{|l|}{ Myelinated sheath } \\
\hline A & 35 & 1.65 & 0.82 & 1743 & 758 \\
\hline$P$ & 123 & 2.14 & 0.72 & 1484 & 676 \\
\hline $\begin{array}{r}F(\mathrm{df}): \\
\mathrm{p}: \\
\text { Post hoc }\end{array}$ & \multicolumn{3}{|c|}{$\begin{array}{c}11.508(1,156) \\
0.001 \\
\mathrm{P}>\mathrm{A}\end{array}$} & \multicolumn{2}{|c|}{$\begin{array}{l}3.791(1,156) \\
0.053^{\text {ns }}\end{array}$} \\
\hline
\end{tabular}

Table 2. Adjusted metabolism rates (AMR) at $1{ }^{\circ} \mathrm{C}$ of mesopelagic/bathypelagic

C6M), feeding type (carnivore, detritivore or suspension feeder), and myelinated or not myelinated for 1-way ANOVA (Table 3). Because there were fewer data than for the other groups, the C5 males or females or with no sex notations were combined as a group 'C5'. The data without stage determinations and the data from 2 specimens at different stages were omitted. The results of analyses were similar to those obtained for $\mathrm{AMR}$ at $1^{\circ} \mathrm{C}$ (Table 2); the effect of stage/sex to ETS activity was insignificant, carnivores exhibited lower ETS activities than suspension feeders, and non-myelinated copepods showed lower ETS activities than myelinated ones. The depth of occurrence among the groups or types was consistently not the significant source of variation across the 3 analyses, as was the case in the analysis of AMR above.

\section{Relative importance of various factors}

Having designated depth of occurrence, stage/sex, feeding type and presence/absence of myelin sheath enveloping axons as independent variables, the attributes of these variables were analyzed using a stepwise mulscatulata C6F from the M zone) to $4.43 \mathrm{mg}$ (Gaidius robustus $\mathrm{C} 6 \mathrm{~F}$ from the UB zone). The ETS activities at $10^{\circ} \mathrm{C}$ ranged from 0.03 (E. pseudaffinis $\mathrm{C} 4$ from the $\mathrm{LB}$ zone) to $9.15 \mu \mathrm{O} \mathrm{O}_{2}$ ind. $^{-1} \mathrm{~h}^{-1}$ (G. robustus C6F from the UB zone) (Appendix 2). A plot of ETS activities against body protein on log-log scales showed a pattern of increase with an increase in body protein (Fig. 1B), as was also seen for respiration-body nitrogen relationships (Fig. 1A). The intercept of the regression line of the $E$ zone data was the highest, with intercepts for $M$, UB and LB zones progressively lower. Mean ETS activities $\left(\mu \mathrm{l} \mathrm{O}_{2} \mathrm{mg}\right.$ protein ${ }^{-0.8} \mathrm{~h}^{-1}$ ) at $10^{\circ} \mathrm{C}$ of copepods from the E, M, UB and LB zones were 3.6, 2.8, 2.0 and 1.9, respectively (Appendix 2).

One-way ANOVA and subsequent between-means tests (Bonferroni-test) revealed that at $10^{\circ} \mathrm{C}$ ETS activities $\left(\mu \mathrm{l} \mathrm{O} \mathrm{O}_{2} \mathrm{mg}\right.$ protein $\left.{ }^{-0.8} \mathrm{~h}^{-1}\right)$ of copepods from the $\mathrm{E}$, $\mathrm{M}, \mathrm{UB}$ and LB zones were significantly inhomogeneous $(F=8.01$, df $=3,93, \mathrm{p}<0.001)$, and betweenmeans differences were $E=M>U B=L B$ at $\mathrm{p}=0.05$.

Similarly to AMR at $1{ }^{\circ} \mathrm{C}$, ETS activity data $\left(\mu \mathrm{l} \mathrm{O}_{2} \mathrm{mg}\right.$ protein ${ }^{-0.8} \mathrm{~h}^{-1}$ at $10^{\circ} \mathrm{C}$ ) from the 4 bathymetric levels were pooled and grouped into stage/sex (C5, C6F or tiple regression method (Sokal \& Rohlf 1995). Linear regression models adopted were:

$A M R=U B+L B+C 5 M+C 5 F+C 6 F+D+S+P+$ constant and

$E T S=E+U B+L B+C 5+C 6 F+D+S+P+$ constant

where $A M R$ is $A M R$ at $1^{\circ} \mathrm{C}$ of copepods from the $\mathrm{M}$ through the LB zones (Appendix 1), ETS is ETS at $10^{\circ} \mathrm{C}$ of copepods from the $\mathrm{E}$ through the LB zones (Appendix 2); $E, U B$ and $L B$ are dummy variables on depth; C5, C5M, C5F and C6F are dummy variables on stage/sex, $D$ and $S$ are dummy variables on feeding type, and $P$ is the presence of myelinated sheath. The definitions of these dummy variables are summarized in Appendix 3 (www.int-res.com/articles/suppl/ m322p199_app.pdf). Independent variables are added if $p \leq 0.05$ and removed if $p \geq 0.10$. The calculation was conducted using SPSS ver. 11.5.

Depth category, feeding type and reaction speed significantly affected AMR at $1^{\circ} \mathrm{C}$. The effect of depth was negative, and detritivores and suspension feeders had greater AMRs than carnivores. The species with 
Table 3. Electron transport system (ETS) activities at $10^{\circ} \mathrm{C}$ of mesopelagic/ bathypelagic copepods split into 3 stage/sex groups, 3 feeding types (C: carnivore, D: detrivore, S: suspension feeder) or 2 groups based on the absence (A) or presence (P) of myelinated sheath. Values are $\mathrm{n}$ (the number of datasets), mean and SD. Differences between groups or types were examined via 1-way ANOVA. To provide sufficient data for analysis female and male data for C5 were combined. Significant differences between paired means were tested using the Bonferroni-test at the $p=0.05$ level. ns: not significant ( $p>0.05$ )

\begin{tabular}{|c|c|c|c|c|c|}
\hline \multirow[t]{2}{*}{ Source of variation } & \multicolumn{3}{|c|}{$\begin{array}{c}\text { ETS }\left(\mu l \mathrm{O}_{2} \text { mg protein }{ }^{-0.8} \mathrm{~h}^{-1}\right) \\
\text { at } 10^{\circ} \mathrm{C}\end{array}$} & \multicolumn{2}{|c|}{ Depth (m) } \\
\hline & $\mathrm{n}$ & Mean & $\mathrm{SD}$ & Mean & $\mathrm{SD}$ \\
\hline \multicolumn{6}{|l|}{ Stage/sex } \\
\hline $\mathrm{C} 5$ & 21 & 1.98 & 1.25 & 1286 & 802 \\
\hline $\mathrm{C} 6 \mathrm{~F}$ & 60 & 2.77 & 1.44 & 1233 & 900 \\
\hline \multirow[t]{2}{*}{$\mathrm{C} 6 \mathrm{M}$} & 7 & 2.46 & 1.33 & 1768 & 996 \\
\hline & \multicolumn{3}{|c|}{$2.526(2,85)$} & \multicolumn{2}{|c|}{$\begin{array}{c}1.143(2,85) \\
0.324^{\text {ns }}\end{array}$} \\
\hline \multicolumn{6}{|l|}{ Feeding type } \\
\hline $\mathrm{C}$ & 40 & 2.00 & 1.36 & 1412 & 880 \\
\hline $\mathrm{D}$ & 9 & 2.97 & 1.59 & 1500 & 810 \\
\hline $\mathrm{S}$ & 48 & 2.73 & 1.39 & 1294 & 935 \\
\hline $\begin{array}{r}F(\mathrm{df}): \\
p \\
\text { Post hoc }\end{array}$ & & $\begin{array}{r}659(2, \\
0.029 \\
S>C\end{array}$ & & \multicolumn{2}{|c|}{$\begin{array}{l}0.303(2,94) \\
0.739^{\text {ns }}\end{array}$} \\
\hline \multicolumn{6}{|l|}{ Myelinated sheath } \\
\hline $\mathrm{A}^{\mathrm{T}}$ & 36 & 2.03 & 1.41 & 1396 & 983 \\
\hline \multirow[t]{2}{*}{$\mathrm{P}$} & 61 & 2.70 & 1.40 & 1342 & 848 \\
\hline & & $\begin{array}{r}054(1, \\
0.027 \\
P>A\end{array}$ & & \multicolumn{2}{|c|}{$\begin{array}{l}0.080(1,95) \\
0.777^{\text {ns }}\end{array}$} \\
\hline
\end{tabular}

sheath enveloping axons had greater AMRs than those without it. No significant effects of stage/sex on AMR were detected in this analysis (Table 4). Compared with $\mathrm{AMR}$ at $1^{\circ} \mathrm{C}$, the effect of stage/sex on ETS at $10^{\circ} \mathrm{C}$ was significant, but the effects of feeding type and reaction speed were not. Differences in significant independent variables between AMR and ETS may be due to greater variations of the latter data which blurred the results. Coefficient of variations (SD/mean, $\%$ ) calculated from AMR data (Table 2) and ETS data (Table 3) were 29 to $39 \%$ and 52 to $63 \%$, respectively, for the 3 or 4 stage/sex groups; 29 to $40 \%$ and 51 to $68 \%$, respectively, for the 3 feeding types; and 34 to $50 \%$ and 52 to $69 \%$, respectively, for with/without myelinated sheath groups. Nevertheless, the results of stepwise regression analysis (Table 4) indicated clearly that the depth of occurrence is a valid variable affecting either the $\mathrm{AMR}$ at $1^{\circ} \mathrm{C}$ of $\mathrm{M}$ to $\mathrm{LB}$ zone copepods or ETS at $10^{\circ} \mathrm{C}$ of $\mathrm{E}$ to LB zone copepods. Detail analysis of this follows by adding the E zone data to the AMR at $1^{\circ} \mathrm{C}$.

\section{Depth-related patterns}

Of the 90 respiration data on 8 Arctic/Antarctic copepods in Ikeda et al. (2001) supplemented as the E zone data in the present study, the mean and SD values were -0.04 and $1.33^{\circ} \mathrm{C}$ for temperature, 0.61 and $0.43 \mu \mathrm{O}_{2}$ ind. ${ }^{-1} \mathrm{~h}^{-1}$ for respiration rate, 0.08 and $0.08 \mathrm{mg}$ for body $\mathrm{N}, 0.57$ and $0.66 \mathrm{mg}$ for body C, 2.09 and $1.13 \%$ body $\mathrm{C} \mathrm{d}^{-1}$ for $\mathrm{SR}$, and 5.11 and $1.27 \mu \mathrm{O}_{2}(\mathrm{mg} \text { body } \mathrm{N})^{-0.8}$ $\mathrm{h}^{-1}$ for AMR at $1^{\circ} \mathrm{C}$.

Assigning the mid-point of the sampling interval as a representative habitat depth of copepods from the E, M, UB and LB zones (e.g. 50, 750, 1500 and $2500 \mathrm{~m}$ depth, respectively), the effect of depth of occurrence (m) on the AMR at $1^{\circ} \mathrm{C}$ and ETS $\left(\mu \mathrm{l} \mathrm{O}{ }_{2}\right.$ mg protein $\left.{ }^{-0.8} \mathrm{~h}^{-1}\right)$ at $10^{\circ} \mathrm{C}$ of copepods was analyzed by using a regression model: AMR (or ETS) $=\alpha+\beta$ ln depth, where $\alpha$ and $\beta$ are constants. Regression equations thus yielded were: $\mathrm{AMR}=8.554 \times 0.897 \mathrm{ln}$ depth $(\mathrm{r}=0.991$, $\mathrm{df}=2, \mathrm{p}<0.01$; Fig. 2), and ETS $=5.403-$ $0.445 \ln$ depth $(\mathrm{r}=0.966, \mathrm{df}=2, \mathrm{p}<0.05)$, indicating that reduction with depth is significant for both AMR and ETS.

\section{DISCUSSION}

\section{Methodological issues}

With increasing depth, hydrostatic pressure increases while temperature decreases in most sea regions. Thus, mesopelagic and bathypelagic copepods brought from depth to the deck of the ship may be under the stresses of rapid changes in hydrostatic pres-

Table 4. Attributes of the independent variables depth of occurrence $(E, U B$ or $L B)$, stage/sex $(C 5, C 5 M, C 5 F$ or $C 6 F)$, feeding type $(D$ : detritivore, $S$ : suspension feeder) or presence $(P)$ of myelinated axons to AMR at $1^{\circ} \mathrm{C}$ of $\mathrm{M}$ to UB zone copepods or ETS at $10^{\circ} \mathrm{C}$ of $\mathrm{E}$ to UB zone copepods as revealed by stepwise multiple regression analysis.,+++++ or + indicates the coefficient are all positive and significant at $\mathrm{p}<0.001, \mathrm{p}<0.01$ and $\mathrm{p}<0.05$, respectively. --- , -- or indicates the coefficients are all negative and significant at $\mathrm{p}<0.001, \mathrm{p}<0.001$ and $p<0.05$, respectively. na: not applicable. ns: not significant. For details see

'Discussion: Does the 'visual interactions' hypothesis explain the pattern?'

\begin{tabular}{|lccccccccccc|}
\hline & $E$ & $U B$ & $L B$ & $C 5$ & $C 5 M$ & $C 5 F$ & $C 6 F$ & $D$ & $S$ & $P$ \\
\hline AMR & na & --- & --- & na & ns & ns & ns & +++ & +++ & +++ \\
ETS & ++ & ns & - & -- & na & na & ns & ns & ns & ns \\
\hline
\end{tabular}




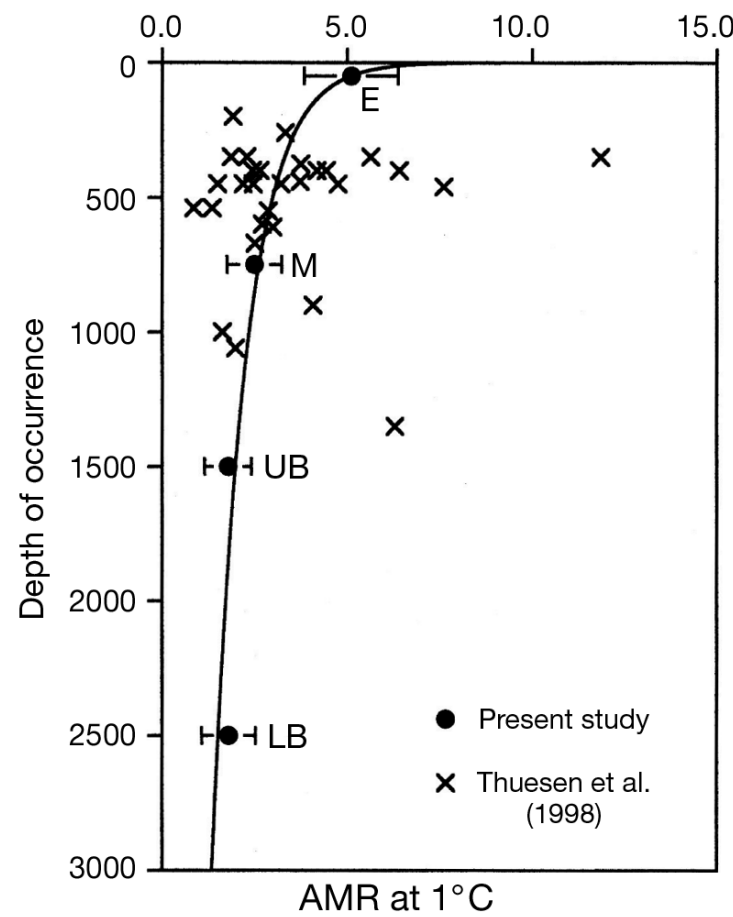

Fig. 2. Relationship between AMR ( $y: \mu l \mathrm{O}_{2} \mathrm{mg}$ body $\mathrm{N}^{-1} \mathrm{~h}^{-1}$ ) at $1^{\circ} \mathrm{C}$ and depth of occurrence $(x: \mathrm{m})$ of marine pelagic copepods. Values are mean $\pm \mathrm{SD}$ for the $\mathrm{E}$ (mean: $50 \mathrm{~m}$ ), $\mathrm{M}(750 \mathrm{~m}), \mathrm{UB}(1500 \mathrm{~m})$ and LB $(2500 \mathrm{~m})$ zones, and a regression line through the means is $y=8.554-0.897 \ln x$ $(\mathrm{r}=0.991)$. The figure includes data from Thuesen et al. (1998). (Only data with complete sets of respiration rate, capture depth and protein content are shown)

sure (decompression effect) and water temperature (temperature shock). In the present study, the decompression effect on the respiration rates of copepods was shown to be not significant in the experiments in which the specimens were incubated in pressurized chambers (100 atm) and non-pressurized chambers (1 atm) (see 'Results'). The lack of decompression effects on respiration rates of deep-sea zooplankton has also been documented by several workers (Childress \& Thuesen 1993, and literature therein). With regard to temperature shock, the present study site (western subarctic Pacific) is characterized by an annual range of surface temperatures which is 2 to $18^{\circ} \mathrm{C}$ at most, and that of mesopelagic/bathypelagic zones to be 1.5 to $3^{\circ} \mathrm{C}$ (Kobari \& Ikeda 1999, Tsurushima et al. 2002). Clearly, no temperature shock will occur during the winter-early spring season when the water column is nearly homogeneous. In other seasons, when the surface temperature exceeded $10^{\circ} \mathrm{C}$, we used the closing cod-end, which has a similar function to the 'thermally protecting cod-ends' described by Childress et al. (1978).

Dissolved oxygen is of special interest since an oxygen minimum layer (OML) has been found in mesopelagic zones over vast regions of the world's ocean, and respiration rates of zooplankton are more or less affected by oxygen availability (HernandezLeon \& Ikeda 2005b). According to Childress's (1975) experiments, most pelagic crustaceans (mysids, decapods, euphausiids, copepods, etc.) from the OML off Southern California are metabolic 'regulators' (see Ikeda et al. 2000) and could maintain stable respiration rates to at least the lowest oxygen concentrations they encounter in nature. On the other hand, respiration rates of zooplankton living in oxygen-rich environments are metabolic 'conformers', whose respiration rates are largely dependent on the oxygen concentration in surrounding water (Davenport \& Trueman 1985). From a technical viewpoint, respiration rates of metabolic regulators can be determined using oxygen-saturated seawater, but the rates of metabolic conformers need to be measured using seawater with oxygen concentrations close to that of the in situ concentration. Since little is known about respiration rate-oxygen concentrations relationships for deep-sea copepods living in the moderate OML of the western subarctic Pacific, freshly collected seawater, passed through $10 \mu \mathrm{m}$ mesh netting without appreciable changes in dissolved oxygen, was used throughout the present study.

In addition to these extreme types, regulators and conformers, there may be intermediate types but they have been little studied. Compared with the OML off Southern California (ca. $4 \%$ oxygen saturation at $800 \mathrm{~m}$ depth, cf. Thuesen et al. 1998), the OML of the present study site (western subarctic Pacific) is moderate (10 to $30 \%$ oxygen saturation at 1000 to $2000 \mathrm{~m}$, see 'Methods and materials'). If the level of dissolved oxygen were a major factor affecting the respiration rates of copepods in the present study, the copepods from the OML (1000 to $2000 \mathrm{~m})$ would have exhibited the lowest $\mathrm{AMR}$ at $1{ }^{\circ} \mathrm{C}$, but this was not the case (Fig. 2).

Despite every effort to avoid artifacts so as to obtain realistic respiration rates for live copepods brought from depth, the validity of the results is not necessarily very certain. Enzyme assay of intermediary metabolism is another measure of respiration rates, a measure almost free from the problems associated with recovery of copepods from depth. This follows from the premise that the amount of enzymes in a specimen does not vary appreciably over a short time scale (see Ikeda et al. 2000). As such, the activities of citrate synthase (CS), lactate dehydrogenase (LDH) and pyruvate kinase (PK) as indicators of aerobic metabolism, anaerobic metabolism and glycolytic flux, respectively, have been determined together with respiration measurements on deep-sea pelagic animals (see Childress 1995). However, both LDH and CS activities were 
found to be poorly correlated with respiration rates of the deep-sea copepods (Thuesen et al. 1998). ETS activities adopted in the present study have been shown to be closely associated with respiration rates of marine zooplankton (King \& Packard 1975b) and used as a practical method to estimate community metabolism of deep-sea zooplankton (see Hernandez-Leon \& Ikeda 2005b). Since the theoretical ETS:respiration ratio is 2 (Owens \& King 1975) and is little affected by temperature or body mass of zooplankton tested (King \& Packard 1975b), the validity of respiration data on copepods from the deep sea obtained in this study can be examined by comparing them with the ETS data. This comparison, i.e. ETS $\left(\mu l \mathrm{O}_{2} \mathrm{mg} \mathrm{N}^{-0.8} \mathrm{~h}^{-1}\right)$ at $1^{\circ} \mathrm{C}$ in Appendix 2 versus AMR $\left(\mu l \mathrm{O}_{2} \mathrm{mg} \mathrm{N}^{-0.8} \mathrm{~h}^{-1}\right)$ at $1^{\circ} \mathrm{C}$ in Appendix 1, showed that the ETS:respiration ratios (2.0 to 2.2) were close to the theoretical value (2.0) for the M, UB and LB zone copepods, excepting an anomalous ratio (1.4) for E zone copepods (Fig. 3). The anomalous ETS:respiration ratio for E zone copepods may be indicative of an invalid comparison between copepods living in Arctic/Antarctic waters (respiration data) and those living in the western subarctic Pacific waters (ETS data) with no common species between them.

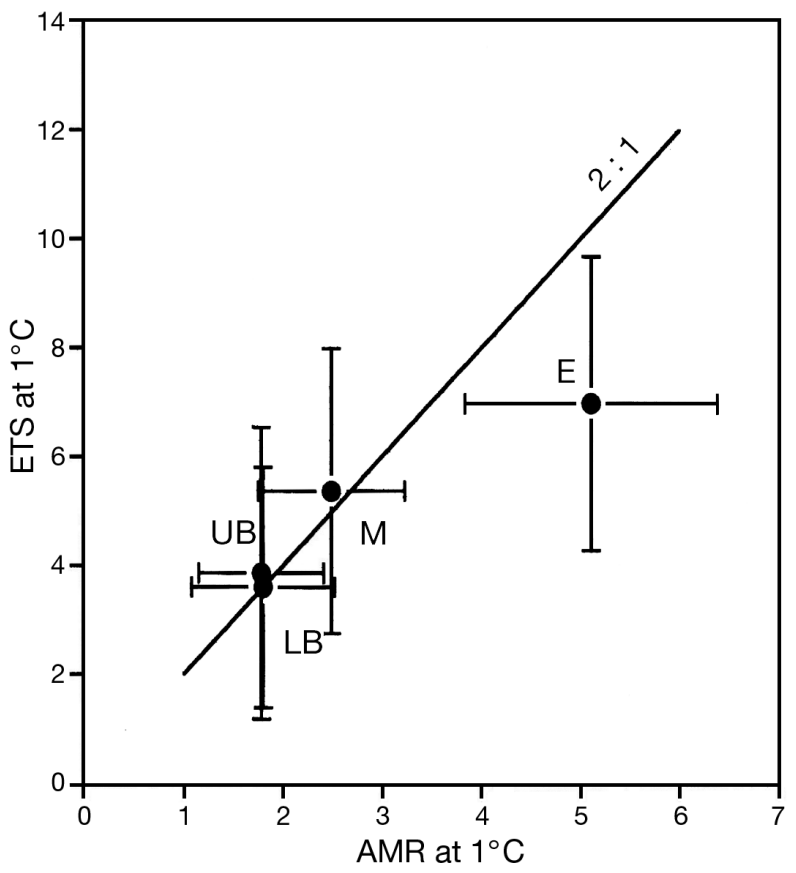

Fig. 3. Relationship between AMR $\left(\mu \mathrm{l} \mathrm{O}_{2} \mathrm{mg}\right.$ body $\left.\mathrm{N}^{-1} \mathrm{~h}^{-1}\right)$ at $1^{\circ} \mathrm{C}$ and ETS at $1^{\circ} \mathrm{C}\left(\mu \mathrm{l} \mathrm{O}\right.$ mg body $\left.\mathrm{N}^{-1} \mathrm{~h}^{-1}\right)$ of the $\mathrm{E}, \mathrm{M}$, UB and LB zone copepods. The theoretical ETS:respiration ratio (2.0) was superimposed for comparison. Note that the ratios of $\mathrm{M}, \mathrm{UB}$ and $\mathrm{LB}$ zone copepods are close to the theoretical one, but the ratio of the E zone copepods deviated from the theoretical one. See 'Discussion: Methodological issues' for details

\section{Depth-related zooplankton metabolism}

As part of a study integrating mesozooplankton community respiration over the full depth of the oceans and across all latitudes, Hernandez-Leon \& Ikeda (2005a) compiled zooplankton community respiration data (mostly from ETS activity data) in mesopelagic and bathypelagic zones determined at in situ temperatures. According to their results, the community respiration rates of mesopelagic and bathypelagic mesozooplankton expressed as SR of this study were $4 \%$ body $\mathrm{C} \mathrm{d}^{-1}$ and $1 \%$ body $\mathrm{C} \mathrm{d}^{-1}$, respectively. Compared with present results on pelagic copepods in Appendix 1, it is evident that while their bathypelagic SR is close to the present results $\left(0.6 \%\right.$ body $\left.\mathrm{C} \mathrm{d}^{-1}\right)$, the mesopelagic SR is much higher than the present results $(1.1 \%$ body $\mathrm{C}$ $\mathrm{d}^{-1}$ ). Differences in modal sizes of component zooplankters, definitions of 'mesopelagic' zone (200 to $1000 \mathrm{~m}$ in Hernandez-Leon \& Ikeda 2005a in contrast to 500 to $1000 \mathrm{~m}$ in the present study) and regional thermal regimes (for example, 7 to $>10^{\circ} \mathrm{C}$ in the Northest Atlantic, cf. Koppelman \& Weikert 1999, in contrast to $3^{\circ} \mathrm{C}$ at the present study site) are all likely causes for the different results for mesopelagic SR in these 2 studies.

In addition to a ETS-based study on community respiration of zooplankton from the deep-sea, Thuesen et al. (1998) determined respiration rates on 34 mesopelagic/bathypelagic (mostly from $<2000 \mathrm{~m}$ ) copepods off California. The copepod families used in their experiments are common to those of the present study. The experiments of Thuesen et al. (1998) were conducted at $5^{\circ} \mathrm{C}$ and the body mass of copepods was expressed as WW or protein units (see Table 1 in their paper). To make a comparison with the present results possible, their data were converted to AMR $\left(\mu l \mathrm{O}_{2} \mathrm{mg}\right.$ $\mathrm{N}^{-0.8} \mathrm{~h}^{-1}$ ) at $1^{\circ} \mathrm{C}$ by using the equation: protein $=5 \times \mathrm{N}$ (T. Ikeda unpubl. data) and $Q_{10}=2$ and plotted against the depth of collection (Fig. 2). It is clear that most of their copepods were from a depth of around $500 \mathrm{~m}$ and therefore appropriate for comparison with the copepods from the $\mathrm{E}$ and $\mathrm{M}$ zones in the present study. This comparison showed that the Thuesen et al. (1998) copepod data (converted to $\mathrm{AMR}$ at $1^{\circ} \mathrm{C} ; 3.33 \pm 1.67, \mathrm{n}=29$ ) are greater than those of the $\mathrm{M}$ zone copepods $(t=$ 3.17 , df $=81, \mathrm{p}=0.002$ ) but less than the E zone copepods $(t=4.58, \mathrm{df}=117, \mathrm{p}<0.001)$ in the present study. If one takes into account a rapid decline in respiration rates from the epipleagic to the mesopelagic zone (cf. Fig. 2) and the fact that some copepods from $<500 \mathrm{~m}$ were used in the study by Thuesen et al. (1998), the results of these 2 studies are in good agreement.

In contrast to the present results showing a depthrelated decline in respiration rates, Thuesen et al. (1998) concluded that the respiration rates of copepods 
do not change with the depth of their occurrence. Two possible sources of error may be considered for the conclusions reached by Thuesen et al. (1998). First, epipelagic respiration data used in their analysis were not their own but were data cited from Champalbert \& Gaudy (1972) and Gaudy (1975) which were obtained using different experimental procedures. Respiration rates of marine zooplankton are highly variable depending on experimental conditions, and one way to minimize this problem is to use data generated by the same worker in which the experimental procedures are standardized (Ikeda 1985). Second, the number of data and the bathymetric range (10 data from a depth $>500 \mathrm{~m}$, with a maximum of $1350 \mathrm{~m}$, cf. Fig. 2) in the Thuesen et al. (1998) study might not have been sensitive enough to detect the lower mesopelagic/bathypelagic respiration rates, which were on the order of one-half to one-third that of epipelagic respiration (Fig. 2).

In order to examine whether or not the present results on mesopelagic and bathypelagic copepod respiration are unique, the $\mathrm{M}$ and UB zone data were pooled (i.e. composite data between 500 to $2000 \mathrm{~m}$ depth) and compared with those of non-copepod pelagic animals such as micronektonic crustaceans (mostly mysids and decapods) off Southern California (Childress 1975) and in Antarctic waters (Ikeda 1988), and micronektonic fishes off Southern California (Torres et al. 1979) (Table 5). While original datasets of these workers are from broad bathymetric zones, only those from 500 to $2000 \mathrm{~m}$ depth were selected for this comparison (minimum depth of occurrence, MDO, defined as the depth below which about $90 \%$ of the population lives [Childress 1995] was taken as the depth sampled in this calculation). The respiration rates of these non-copepod crustaceans off Southern California (rates recorded at 30 to $70 \mathrm{~mm} \mathrm{Hg} \mathrm{O}_{2}$ partial pressure in Childress 1955) and in Antarctic waters (rates determined with a sealed chamber method similar to that used in the present study but using larger glass bottles) and of fishes ('routine' rates in Torres et al. 1979) were assumed to approximate the in situ respiration rate of animals. These rates were then converted to AMR $\left(\mu \mathrm{l} \mathrm{O}_{2} \mathrm{mg} \mathrm{N}^{-0.8} \mathrm{~h}^{-1}\right)$ at $1^{\circ} \mathrm{C}$, adopting the same body exponent (0.8) and $Q_{10}$ value (2) used for copepods in our study. While the resulting AMRs of these 4 studies are significantly different $(F=6.37, \mathrm{df}=$ $3,133, \mathrm{p}<0.001$ ), and pairwise comparison between means showed that the respiration rates of micronektonic crustaceans from Antarctic waters were significantly greater than those of crustaceans from waters off Southern California and of copepods in the present study, the 4 mean AMRs at $1{ }^{\circ} \mathrm{C}$ surprisingly fell into into a narrow range of 2 to $3 \mu \mathrm{O}_{2} \mathrm{mg} \mathrm{N}^{-0.8} \mathrm{~h}^{-1}$. If one considers the diverse taxa (crustaceans and fishes), broad size range ( 0.03 to $670 \mathrm{mg} \mathrm{N}$ ) and distant study sites (North Pacific to Antarctic waters) of these studies, the agreement is very striking.

\section{Does the 'visual interactions' hypothesis explain the pattern?}

Daylight only penetrates the upper $1000 \mathrm{~m}$ in the ocean, and the only light available for vision below $1000 \mathrm{~m}$ depth comes from the bioluminescent flashes produced by the marine animals themselves (cf. Warrant \& Locket 2004). The absence of shelter in the pelagic environment means that a well-developed swimming ability (= higher respiration rates) is essential in species inhabiting the well-illuminated epipelagic zones. The 'visual interactions' hypothesis proposed by Childress (1995) predicts a rapid decline in metabolic rates with increasing depth of occurrence for pelagic animals with developed visual perception systems (e.g. eyes). This is because the vision-aided reaction distance in prey-predator relationships decreases downward due to diminishing light; thus, progressively less energy expenditure is required for vision-aided prey/predator reactions with increasing depth. This explanation is also supported by the observations that the protein (= muscle) concentration in the body declines in deeper-living micronektonic fishes and large crustaceans (Childress \& Nygaard 1973, 1974).

Copepods have sensitive chemo- and/or mechanoreceptors but no visual perception (Mauchline 1998). Exceptions to this are a group of copepods (Cephalophanes spp.) that have a highly developed light reflector (Nishida et al. 2002) and some pontellids that have well-developed ocelli and associated lenses (Park 1966), both of which are considered to be functional for capturing prey, escaping from predators or mating. However, such exceptional copepods were not included in our study. For pelagic animals lacking visual perception systems like copepods, the visual interactions hypothesis predicts that the range of reaction does not change with increasing habitat depths and, hence, their metabolic rates are not affected by the depth of occurrence. Contrary to the prediction above, the present results indicate that the respiration rates of epipelagic copepods are reduced to about onethird toward the upper-bathypelagic zone (Fig. 2), and the reduced rates expressed as AMR at $1^{\circ} \mathrm{C}$ are comparable to those of micronektonic fishes and crustaceans inhabiting the same depth zone (Table 5).

Thus, our results suggest that a reduction in respiration rates with depth occurs in pelagic animals irrespective of whether or not they have visual perception systems. Since our stepwise multiple regression analyses revealed that, in addition to the depth of 
Table 5. Metabolic comparison of micronektonic crustaceans and fishes and planktonic copepods occurring from 500 to $2000 \mathrm{~m}$ depth. Temperatures and various body mass and respiration rate units were all standardized to $\mathrm{AMR}$ at $1^{\circ} \mathrm{C}$. WW $=\mathrm{wet}$ weight, DW = dry weight

\begin{tabular}{|c|c|c|c|c|c|c|}
\hline & Study site & $T\left({ }^{\circ} \mathrm{C}\right)$ & $\mathrm{n}$ & $\begin{array}{l}\text { - Original units } \\
\text { Body mass }\end{array}$ & Respiration rate & $\begin{array}{c}\text { AMR at } 1^{\circ} \mathrm{C} \\
\left(\mu l \mathrm{O}_{2} \mathrm{mg} \mathrm{N}^{-0.8} \mathrm{~h}^{-1}\right)\end{array}$ \\
\hline $\begin{array}{l}\text { Micronektonic crustaceans } \\
\text { (Childress 1975) }\end{array}$ & Off Southern California & 5 & 10 & $0.07-48.2 \mathrm{~g} \mathrm{WW}$ & $\begin{array}{c}0.0015-0.036 \\
\mu l \mathrm{O}_{2} \mathrm{mg} \mathrm{WW}^{-1} \mathrm{~h}^{-1}\end{array}$ & $1.97 \pm 0.64$ \\
\hline $\begin{array}{l}\text { Micronektonic crustaceans } \\
\text { (Ikeda 1988) }\end{array}$ & Antarctic waters & -1 to 0.3 & 7 & $50-403 \mathrm{mg} \mathrm{DW}$ & $\begin{array}{c}2.8-63.3 \\
\mu l \mathrm{O}_{2} \text { ind }^{-1} \mathrm{~h}^{-1}\end{array}$ & $3.32 \pm 1.08$ \\
\hline $\begin{array}{l}\text { Micronektonic fishes } \\
\text { (Torres et al. 1979) }\end{array}$ & Off Southern California & 5 & 9 & $2.9-110 \mathrm{~g} \mathrm{WW}$ & $\begin{array}{c}0.005-0.026 \\
\mu l \mathrm{O}_{2} \mathrm{mg} \mathrm{WW}^{-1} \mathrm{~h}^{-1}\end{array}$ & $2.87 \pm 1.60$ \\
\hline $\begin{array}{l}\text { Copepods } \\
\text { (Present study) }\end{array}$ & $\begin{array}{l}\text { M/UB zones, } W \\
\text { subarctic Pacific }\end{array}$ & 2 to 3 & 111 & $0.025-2.38 \mathrm{mg} \mathrm{N}$ & $\begin{array}{c}0.05-4.16 \\
\mu \mathrm{l} \mathrm{O} \text { ind }^{-1} \mathrm{~h}^{-1}\end{array}$ & $2.13 \pm 0.77$ \\
\hline
\end{tabular}

occurrence, feeding type and phyletic pattern (presence/absence of myelin sheath) are other factors affecting the respiration rates of copepods (Table 4), interactions between these additional factors and the depth of occurrence need to be examined. With regard to feeding type, carnivores were characterized by lower respiration rates than detritivores and suspension feeders. Lower respiration rates (= slower swimming activities) of deep-sea carnivorous copepods are consistent with the observation that they have lower nitrogen contents $(=$ fewer muscles $)(<8 \%$ of DW as compared with $>8 \%$ of DW for detritivores and suspension feeders; Ikeda et al. in press). Respiration rates of copepods belonging to the ancient superfamily Arietelloidea and Centropagoidea (cf. Table 1), characterized by slower escape reactions to the stimuli of predators due to the lack of myelin-like sheaths enveloping nerve fibres (Lenz et al. 2000), were shown to be lower than the rates of the more recent superfamilies (Tables 4 \& 5). However, the slower reaction may not necessarily mean that copepods have a slower swimming speed. For example, Metridia spp., a member of the non-myelinated superfamily Arietelloidea, occur in the epipelagic zone and exhibit respiration rates similar to or higher than copepods with myelinated axons such as Calanus (Ikeda 1989). Nevertheless, our analysis also indicated that neither the feeding types nor phyletic patterns were related closely to the depth of occurrence of copepods ( $p>$ 0.05 , cf. Tables $2 \& 3$ ); therefore, the major cause for the depth-related pattern in the respiration rates (Fig. 2) is something else.

Prior to proposition of the 'visual interactions' hypothesis, Childress (1995) reviewed the possible role that lower temperature, less dissolved oxygen, increased hydrostatic pressure and decreased food supply at depth may play in reducing the metabolic rates of deep-sea pelagic animals (large crustaceans, fishes and cephalopods) and concluded none of them are likely the major cause for this phenomenon. For copepods in the present study, the same conclusion may be applicable for temperature, dissolved oxygen and hydrostatic pressure (see 'Discussion: Methodological issues'). With regard to reduced food supply, the body composition data of copepods from the epipelagic through the abyssopelagic zones show no evidence of food limitation at depth (mostly $\mathrm{C}>60 \%$ of DW, C/N > 6.5 for abyssopelagic copepods, Ikeda 2006). In general, reduced food supply is considered to affect the population size rather than the metabolism of individuals (cf. Childress 1995).

The rapid reduction in respiration rates of pelagic copepods toward the bathypelagic zone in our study may be interpreted as a result of low selective pressure for high activity in copepods in the deep-sea (recently proposed as the 'predation-mediated selection' hypothesis). Copepods living in the illuminated epipelagic zone have the advantage of a rich diet, but they also need to be active enough to avoid predation risk. The following points support this predation-mediated selection hypothesis: (1) While no depth-related pattern in body carbon was observed, body nitrogen (= muscle) of pelagic copepods decreased consistently toward the abyssopelagic zone in the Oyashio region (Ikeda et al. in press). (2) Diel vertical migration (DVM), a predator avoidance behavior characterized by nocturnal ascent, is frequently seen in shallowliving copepods but is lacking in deeper-living copepods (cf. Yamaguchi et al. 2004). (3) The biomass of predators (micronekton) decreases exponentially with increasing depth (Mauchline 1991). (4) The fecundity of deep-living micronekton (Mauchline 1991) and copepods (Yamaguchi et al. 2004) is low as compared to shallow-living counterparts, although a large bathypelagic copepod Valdeiviella insignis, which has as few as 2 eggs per brood, may be an exception (Mauchline 1991). In the light of high diversity of non-visual pelagic animals in the ocean, further study on animals other than copepods is needed to prove/disprove this new 'predation-mediated selection' hypothesis. 
Acknowledgements. We are grateful to C. B. Miller and E. V. Thuesen for their constructive comments, which significantly improved earlier drafts of the manuscript. We thank H. Matsumoto and A. Maeda of the Center for Instrumental Analysis of Hokkaido University for CHN elemental analysis. This study was supported by grant JSPS KAKENSHI 14209001 to T.I.

\section{LITERATURE CITED}

Arashkevich YeG (1969) The food and feeding of copepods in the northwestern Pacific. Oceanology 9:695-709

Champalbert G, Gaudy R (1972) Etude de la respiration chez des copèpods des niveaux bathymètriques varies la règion sud marocaine et canarienne. Mar Biol 12:159-169

Childress JJ (1975) The respiratory rates of midwater crustaceans as a function of depth of occurrence and relation to the oxygen minimum layer off Southern California. Comp Biochem Physiol 50A:787-799

Childress JJ (1995) Are there physiological and biochemical adaptations of metabolism in seep-sea animals? TREE 10:30-36

Childress JJ, Nygaard M (1973) The chemical composition of midwater fishes as a function of depth of occurrence off Southern California. Deep-Sea Res 20:1093-1109

Childress JJ, Nygaard M (1974) Chemical composition and buoyancy of midwater crustaceans as a function of depth of occurrence off Southern California. Mar Biol $27: 225-238$

Childress JJ, Thuesen EV (1993) Effects of hydrostatic pressure on metabolic rates of six species of deep-sea gelatinous zooplankton. Limnol Oceanogr 38:665-670

Childress JJ, Barnes AT, Quetin LB, Robison BH (1978) Thermally protecting cod ends for the recovery of living deepsea animal. Deep-Sea Res 25:419-422

Davenport J, Trueman ER (1985) Oxygen uptake and buoyancy in zooplanktonic organisms from the tropical eastern Atlantic. Comp Biochem Physiol 81A:857-863

Favorite F, Dodimead AJ, Nasu K (1976) Oceanography of the subarctic Pacific region, 1960-1971. Bull Int Pacif Fish Commn 33:1-187

Gaudy R (1975) Etude de la respiration chez des copèpods pèlagiques mèditeraneens (bassin occidental et Mer Ionienne) et de ses variations en fonction de la bathymètrie des espècies et de leur origine gèographique. Mar Biol 29:109-118

Gnaiger E (1983) Calculation on energetic and biochemical equivalents of respiratory oxygen consumption. In: Gnaiger E, Forstner H (eds) Polarographic oxygen sensors. Springer, Berlin, p 337-345

Hernandez-Leon S, Ikeda T (2005a) A global assessment of mesozooplankton respiration in the ocean. J Plankton Res 27:153-158

Hernandez-Leon S, Ikeda T (2005b) Zooplankton respiration. In: del Giorgio PA, Williams PJ le B (eds) Respiration in aquatic ecosystems. Oxford University Press, Oxford, p $57-82$

Ikeda T (1985) Metabolic rates of epipelagic marine zooplankton as a function of body mass and temperature. Mar Biol 85:1-44

Ikeda T (1988) Metabolism and chemical composition of crustaceans from the Antarctic mesopelagic zone. Deep-Sea Res 35:1991-2002

Ikeda T (1989) Are antarcticzooplankton metabolically more cold-adaptate than arctic zooplankton? An intra-generic comparison of oxygen consumption rates. J Plankton Res $11: 619-624$
Ikeda T, Torres JJ, Hernandez-Leon S, Geiger SP (2000) Metabolism. In: Harris RP, Wiebe PH, Lenz J, Skjoldal HR, Huntley M (eds) ICES zooplankton methodology manual. Academic Press, San Diego, CA, p 455-532

Ikeda T, Kanno, Y, Ozaki K, Shinada A (2001) Metabolic rates of epipelagic marine copepods as a function of body mass and temperature. Mar Biol 139:587-596

Ikeda T, Sano F, Yamaguchi A (2004) Metabolism and body composition of a copepod Neocalanus cristatus (Crustacea) from bathypelagic zone of the Oyashio region, western subarctic Pacific. Mar Biol 145:1181-1190

Ikeda T, Yamaguchi A, Matsuishi T (2006) Chemical composition and energy content of deep-sea calanoid copepods in the western North Pacific Ocean. Deep-Sea Res (in press)

Kawamura A (1968) Performance of Peterson type closing net. Bull Plankton Soc Jpn 15:11-12

King FD, Packard TT (1975a) The effect of hydrostatic pressure on respiratory electron transport system activity in marine zooplankton. Deep-Sea Res 22:99-105

King FD, Packard TT (1975b) Respiration and the activity of the respiratory electron transport system in marine zooplankton. Limnol Oceanor 20:849-853

Kobari T, Ikeda, T (1999) Vertical distribution, population structure and life cycle of Neocalanus cristatus (Crustacea: Copepoda) in the Oyashio region, with notes on its regional variations. Mar Biol 134:683-696

Koppelmann R, Weikert H (1999) Temporal changes of deepsea mesozooplankton abundance in the temperate NE Atlantic and estimates of the carbon budget. Mar Ecol Prog Ser 179:27-40

Lenz PH, Hartline DK, Davis AD (2000) The need for speed. I. Fast reactions and myelinated axons in copepods. J Comp Physiol A 186:337-345

Longhurst AR (1985) The structure and evolution of plankton communities. Prog Oceanogr 15:1-35

Lowry OH, Rosebrough NJ, Farr AL, Randall RJ (1951) Protein measurement with the Folin Phenol reagent. J Biol Chem 193:265-275

Mauchline J (1991) Some modern concepts in deep-sea pelagic studies: patterns of growth in the different horizons. In: Mauchline J, Nemoto T (eds) Marine biology: its accomplishment and future prospect. Hokusen-sha, Tokyo, p 107-130

Mauchline J (1998) The biology of calanoid copepods. Adv Mar Biol 33:1-710

Menard HW, Smith SM (1966) Hypsometry of ocean basin provinces. J Geophys Res 71:4305-4325

Nishida S, Ohtsuka S, Parker AR (2002) Functional morphology and food habits of deep-sea copepods of the genus Cephalophanes (Calanoida: Phaennidae): perception of bioluminescence as a strategy for food detection. Mar Ecol Prog Ser 227:157-171

Owens TG, King FD (1975) The measurement of respiratory electron-transport system activity in marine zooplankton. Mar Biol 30:27-36

Park T (1966) The biology of a calanoid copepod Epilabidocera amphrites McMurrich. La Cellule 66:129-251

Sokal RR, Rohlf FJ (1995) Biometry. The principles and practice of statistics in biological research. Freeman, New York

Thuesen EV, Miller CB, Childress JJ (1998) Ecophysiological interpretation of oxygen consumption rates and enzymatic activities of deep-sea copepod. Mar Ecol Prog Ser 168:95-107

Torres JJ, Belman BW, Childress JJ (1979) Oxygen consumption rates of midwater fishes as a function of depth 
of occurrence. Deep-Sea Res 26A:185-197

Tsurushima N, Nojiri Y, Imai K, Watanabe S (2002) Seasonal variations of carbon dioxide system and nutrients in the surface mixed layer at station KNOT $\left(44^{\circ} \mathrm{N}, 155^{\circ} \mathrm{E}\right)$ in the subarctic western North Pacific. Deep-Sea Res II 49:5377-5394

Warrant EJ, Locket NA (2004) Vision in the deep sea. Biol Rev 79:671-712

Editorial responsibility: Howard I. Browman (Associate Editor-in-Chief), Storebø, Norway
Yamaguchi A, Ikeda T, Watanabe Y, Ishizaka J (2004) Vertical distribution patterns of pelagic copepods as viewed from the predation pressure hypothesis. Zool Stud 43:475-485

Yamaguchi A, Watanabe $Y$, Ishida $H$, Harimoto $T$ and 5 others (2002) Community and trophic structures of pelagic copepods down to greater depths in the western subarctic Pacific (WEST-COSMIC). Deep-Sea Res I 49: 1007-1025

Submitted: November 21, 2005; Accepted: February 25, 2006 Proofs received from author(s): September 4, 2006 